\title{
Need for Government Regulation of Organic Foods
}

\author{
Vladimir E. Zhidkov ${ }^{1}$, Andrey G. Hramtsov ${ }^{2}$, Zhanna V. Gornostaeva ${ }^{3}$, Ekaterina S. Alekhina ${ }^{3} \&$ Inna V. \\ Kushnareva $^{3}$ \\ ${ }^{1}$ Technological Institute of Service (branch) of Don State Technical University in Stavropol, Russia \\ ${ }^{2}$ Federal State Autonomous Educational Institution of Higher Professional Education "North Caucasian Federal \\ University", Stavropol, Russia \\ ${ }^{3}$ Institute for the service sector and enterprise (branch) of Don State Technical University in Shakhty, Russia \\ Correspondence: Zhanna V. Gornostaeva, Institute for the service sector and enterprise (branch) of Don State \\ Technical University in Shakhty, Shakhty, st. Shevchenko, 147, Russia. Tel: 7-928-151-0708. E-mail: \\ zh.gornostaeva@mail.ru
}

Received: August 1, 2014 Accepted: September 1, 2014 Online Published: November 14, 2014

doi:10.5539/ass.v10n23p135

URL: http://dx.doi.org/10.5539/ass.v10n23p135

\begin{abstract}
The authors define the concept of demand and prospects of organic foods, identify problems and prospects for the production of organic foods in Russia, exploring features of state regulation of the production of organic foods in different countries and justify the need for state regulation of the production of organic foods in Russia. The authors analyze the results of a sociological survey of 1,000 residents of the Volgograd region in age from 20 to 60 years, determine the structure determination of respondents concepts of organic foods, the structure of the respondents 'opinions on the importance of regular consumption of organic foods, the structure of the respondents' opinions regarding the price for organic food, the structure of respondents 'opinions on the percentage excess of the price for organic food over the price of conventional products, the structure of the respondents' opinions on the proportion of organic foods in the structure of the family budget, identify the main purposes of the production of organic foods, especially compared to the state support for Organic Agriculture economy in the countries of Western Europe, as well as classify the main types of environmental standards.
\end{abstract}

Keywords: government regulation, food safety, organic food, eco-friendly production

\section{Introduction}

Part of the national economic security is food security of the population, which means the availability and the opportunity to purchase food needed for an active and healthy life, in other words - the possibility of uninterrupted supply of food to the population of the physiological nutritional standards.

According to research of the total amount of toxic substances entering the human body, about $70 \%$ comes from food, $20 \%$ air and $10 \%$ water. Therefore, the production of environmentally friendly agricultural products, which conform to the organoleptic, technological and toxicological standards and has no negative impact on human and animal health, the environment, is today one of the most important problems in agricultural production, the main driving force in the competitive struggle for quality performance products.

\section{Method}

At the moment there is no single, universally accepted interpretation of such basic terms as "ecological safety of food" and "organic food", these two concepts are often confused with each other, are used as synonyms, but such confusion is not entirely valid, as it is can lead to misunderstanding the purpose of ecological food production. Without a clear definition of these concepts becomes difficult to identify further areas of ecological agriculture and the food industry.

The concept of "organic food" is broad enough in international practice they include, first, the so-called "natural and organic products" (natural and organic products), consisting entirely of natural ingredients and grown on uncontaminated soils in the second is the addition of products with artificial nutrients that enhance the protective functions of the body (functional foods), and, thirdly, dietary supplements of natural origin (nutraceuticals), which are plant extracts. Obviously, such a gradation ECHPP origin and the extent of their biological usefulness and safety dictated, among other reasons, is also a high level of consumer demand. 
According to some authors, environmentally friendly are those foods that are grown (or received), firstly, on uncontaminated soils and, secondly, without the use of fertilizers and pesticides (Popkova et al. 2013). A similar sense is to invest in the concept of organic food and other professionals working on the introduction of agricultural production in organic agriculture.

The method of a sociological survey is used in this paper as a method of carrying out scientific research. This method involves conducting interviews with respondents. Sociological survey of 1,000 residents of the Volgograd region in age from 20 to 60 years is also used in the research. The survey was aimed at identifying the definition of respondents concepts of organic foods, respondents' views on the importance of regular consumption of organic food, the views of respondents on the price of organic food, the views of respondents on excess interest rates on organic food over the price of conventional products, as well as the respondents' opinions on the proportion of organic food in the structure of the family budget.

\section{Results}

As a result of the opinion poll revealed that under the organic food respondents understand:

1) food produced from raw materials grown on uncontaminated soils ( $45 \%$ of respondents);

2) food produced from raw materials obtained without the use of fertilizers and pesticides ( $40 \%$ of respondents);

3 ) any products produced in compliance with hygiene requirements (15\% of respondents) (Figure 1).

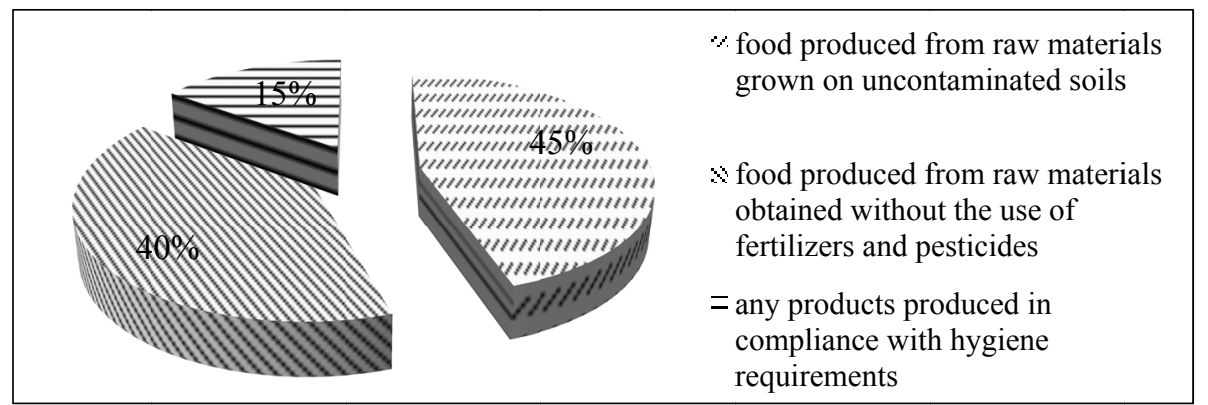

Figure 1. Structure of determination of respondents' concepts of organic foods

It should also be noted that almost $60 \%$ of the Volgograd region recognize the importance of the Volgograd region organic food. Consequently, the production of organic food gets public approval of the majority of inhabitants of the Volgograd region.

Respondents' view on the importance of regular consumption of organic food was as follows (Cheng, 2006):

- $35 \%$ of respondents believe that regular consumption of organic foods is very important;

- $30 \%$ of respondents believe that regular consumption of organic foods more important;

- $25 \%$ of respondents believe that regular consumption of organic foods more important;

- $10 \%$ of respondents believe that regular consumption of organic food is not important (Figure 2).

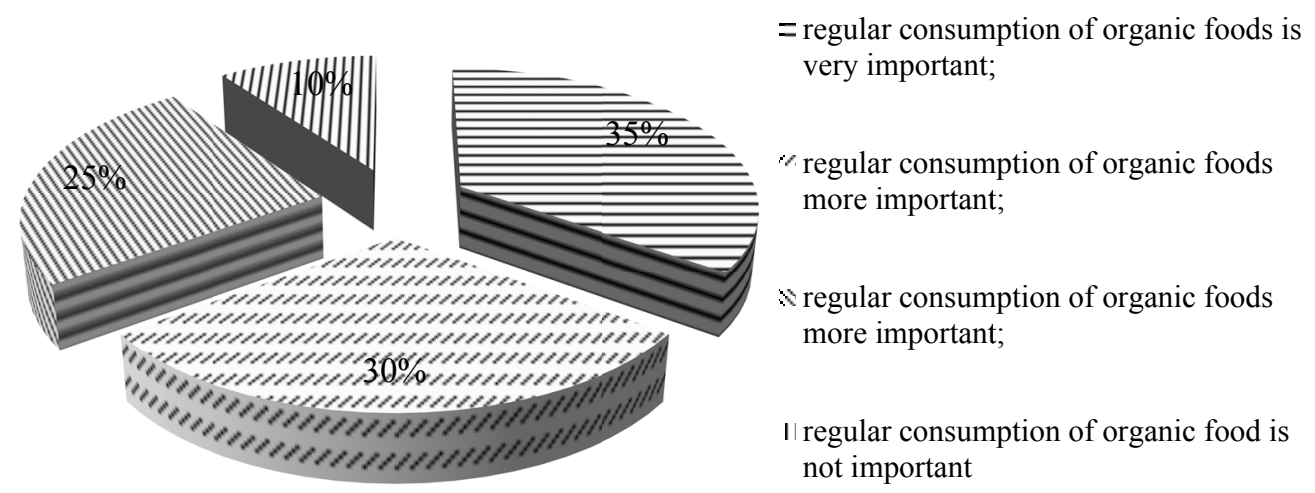

Figure 2. Structure of the respondents' view on the importance of regular consumption of organic foods 
It was also found that regular consumption of organic food is a priority for people aged 36 to 55 years, i.e. have solid experience of life and caring for their own health. However, these age groups are characterized by a marked differentiation in the level of income that does not allow firm conclusions about the magnitude of the potential of effective demand for organic food. For the vast majority of respondents $(65 \%)$ of the regular presence in the diet of organic foods is an important part of the normal life (Volosatova, 2011).

A high percentage of respondents who do not consider vital regular consumption of organic foods (22\%) characteristic mainly for the youngest age groups (20 to 25 years), which may be explained by the low level of environmental awareness and also a low level of monthly income in this age group, which does not allow to differentiate your diet

Respondents' opinions regarding the price of organic food were distributed as follows:

- $65 \%$ of respondents believe that the price of organic foods should be higher than the price of other products;

- $25 \%$ of respondents believe that the price of organic foods should be the same as the price of other products;

- $10 \%$ of respondents believe that the price of organic foods should be lower than the price of other products (Figure 3).

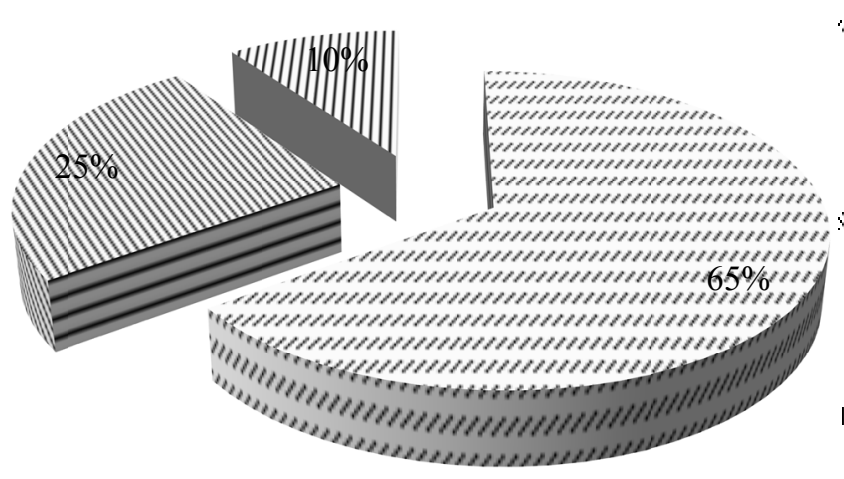

"price of organic foods should be higher than the price of other products;

price of organic foods should be the same as the price of other products;

II price of organic foods should be lower than the price of other products

Figure 3. Structure of the respondents' opinions regarding the price of organic food

As can be seen from Figure 3, slightly more than half of respondents believe that the price of organic foods should be higher than the price of other products; should be higher than the price of other products. This view is expressed most often the most active in the economic sense of the group of respondents aged 20 to 35 years, which is generally not important regular use believe that the price of organic foods in the diet. Some respondents deliberately emphasized that, unless they have a vital use of organic food, then spend "big money" for these products they do not intend to, i.e. "Willingness to pay" in this, the most active, layer of consumer in this case is zero.

On price ECHPP equal the price of a product, or even lower, insist primarily representatives of the older age groups, with an average or low level of monthly income. With all understand the importance of a regular consumption of organic food consumers aged 36 to 45 years rather than willing to pay a high price for the environmental safety of the product.

Among those respondents who believe that the implementation of in-store price of organic foods should be higher than the conventional product, the majority $(65 \%)$ believe that it should exceed the price of a regular product by $5-10 \%$. Views of the other respondents were divided as follows:

- $3-5 \%-15 \%$ of respondents;

- $\quad 10-15 \%-13 \%$ of respondents;

- $\quad 15-20 \%-7 \%$ of respondents (Figure 4).

None of the respondents did not mention the percentage of possible excess of the price of organic food by $15-20 \%$ compared to the price of other products. Consequently, for any additional factors of organic foods in the implementation through the sales network will keep its at-attractiveness to the consumer, if the price exceeds the price of a regular product is not more than $20 \%$. 


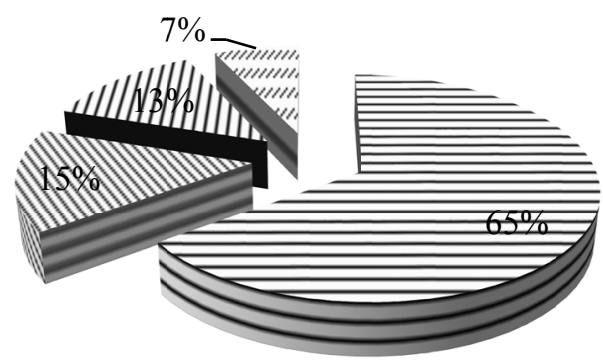

$$
\begin{aligned}
& =3-5 \% \\
& \times 5-10 \% \\
& \text { I } 10-15 \% \\
& =15-20 \%
\end{aligned}
$$

Figure 4. Structure of the respondents' opinions regarding the percentage excess of the price of organic food over the price of conventional products

Consumers' opinions on the proportion of organic food in the structure of the family budget as follows:

- less than $10 \%-25 \%$ of respondents;

- from $10 \%$ to $20 \%-35 \%$ of respondents;

- $\quad$ from $20 \%$ to $30 \%-25 \%$ of respondents;

- $\quad$ from $30 \%$ to $40 \%-15 \%$ of respondents (Figure 5 ).

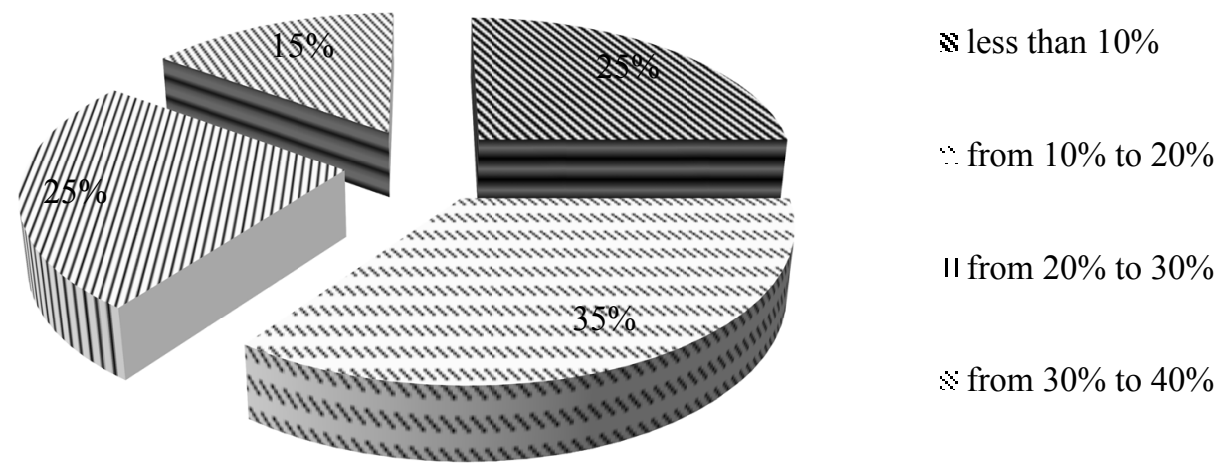

Figure 5. Structure of the respondents' opinions on the proportion of organic food in the structure of the family budget

It was also revealed that the highest willingness to pay for environmental safety of food are mainly characterized by precisely those respondents who consider the regular use of the share of organic food is definitely necessary for himself, that is, consumers aged 36 to 55 years with not a very high level of monthly income (Hopfenbeck, 1994).

Representatives of the age group 36-45 years are willing to spend on the purchase of ECHPP practically all of its budget for the purchase of food products $(40 \%)$. At the same time, representatives of the older age groups, in particular, 56-65 years of age and older, show a significant financial caution, preferring to allocate for the purchase of environmentally friendly products only $10-20 \%$ of the budget.

Consumers with low monthly income are in the age groups 46-55 and over 65 years in the total mass are willing to spend on the purchase of a share of organic food from 20 to $30 \%$ share of the family budget. This fact, we believe a particular issue for potential manufacturers of environmentally friendly products, as it shows the presence of high effective demand. The same follows from the willingness to pay for the environmental safety of the power of consumers aged 36-45 years who believe that the share price of organic food must be equal to the price of conventional foods and ready to spend in connection with the $40 \%$ share of its budget (Danciu, 2005).

Thus, the results of our study show that the production of organic food in the Volgograd region will have strong consumer demand, the implementation of these foods in the distribution network is relatively cost-effective and will have a certain perspective, and ensuring the Volgograd region organic food is important component of food security in the region. 
Today the organic (biological, ecological) agriculture is an alternative development and competitiveness of agriculture sector in most countries of the world. By the minimal use of pesticides and inorganic fertilizers rural producers is pushing the fact that there was a demand for environmentally friendly products, it is appreciated and is more expensive (Popkova \& Tinyakova, 2013a).

At the same time, the European Union law provides that for a "transition period" (the time during which the company must operate in compliance with environmental requirements) produced products cannot be implemented under the logo of "bio", "eco", "organic" and, consequently, agricultural manufacturer does not get able to sell at a higher price. Requirements for the transition period to organic production standards of ecological production differ slightly.

In the European Union the necessary transition period of 36 months before harvest perennial crops (e.g., fruit trees) or 24 months before planting annual crops (e.g., vegetables). Despite this the number of farms transitioning to the system of ecological agriculture systematically grows. For example, in the Czech Republic by the end of 2006 operated 963 eko-farms - 134 more than at the end of 2005, the total land area of the country occupied by organic agriculture amounted to more than 281.5 thousand. Hectares $-6.6 \%$ of farmland. The main objectives of the production of organic foods are:

1) production of food of high nutritional value in sufficient quantities;

2) organization of agricultural production in harmony with the natural ecosystem;

3) foster the formation and strengthening of biological cycles in the system of agricultural production;

4) maintain soil fertility;

5) Increased use of renewable resources in agriculture;

6) establishment of a closed system for the organic substance, and nutrients;

7) keeping of livestock in conditions appropriate to the innate behavior;

8) prevention of pollution of the environment;

9) preservation of genetic diversity;

10) protection of habitats of wild animals and plants, reducing water pollution, soil and air.

Of chemicals of agriculture in Russia are now used by about a third of the arable land. Often, the reason why the impression that most of the domestic land that does not use chemicals, must have good operational and environmental conditions. However, the relatively low use of fertilizers, plant protection chemicals is not the only condition for the good condition of the land (Danciu, 2006).

Serious threat to the land are not related to the conduct of agricultural production manmade pollution caused, in particular, the regional concentration of industrial enterprises. According to Russian scientists in the country over the past 15 years, retired from circulation more than 15 million hectares of arable land, more than 56 million hectares of arable land is low in humus. All this illustrates the need for measures not only to prevent further contamination of land, but also to restore the already polluted areas (Popkova \& Tinyakova, 2013b).

Thus, in order to improve the competitiveness of the Russian agricultural products there is an objective need for ecological and toxicological examination of arable lands. Production of environmentally friendly products is considered potentially competitive segment of the agricultural market. According to various estimates, 20011, sales of organic food in the EU countries, USA and Japan amounted to 19-21 billion. Dollars. USA. In 2012, China exported organic products to 200 million. Dollars. In 2013, the global market for green products was estimated at $\$ 25$ billion. The largest share is occupied by the United States (Faix et al., 1995).

In many advanced economies, "the environmental segment" was demanded by consumer demand (Figure 6).

There is a systematic increase in demand for organic food. So, conducted by Eurobarometer opinion poll in France shows that if in 2011, bio-products acquired 37\% of the respondents, in 2013 already $47 \%$ - buy at least 1 time per month, $27 \%$ - at the earliest opportunity. $21 \%$ of interviewees said that they wished to purchase such products more often.

With bio-products French link their ideas about healthy lifestyles. $87 \%$ of respondents reported a positive impact on the environment Biosaline Agriculture, $85 \%$ - believe that it is better to consume natural foods that do not contain chemical additives, $78 \%$ - believe that organic products have a positive impact on health, $67 \%$ - say their high quality and $62 \%$ - believe that organic food tastes better. 


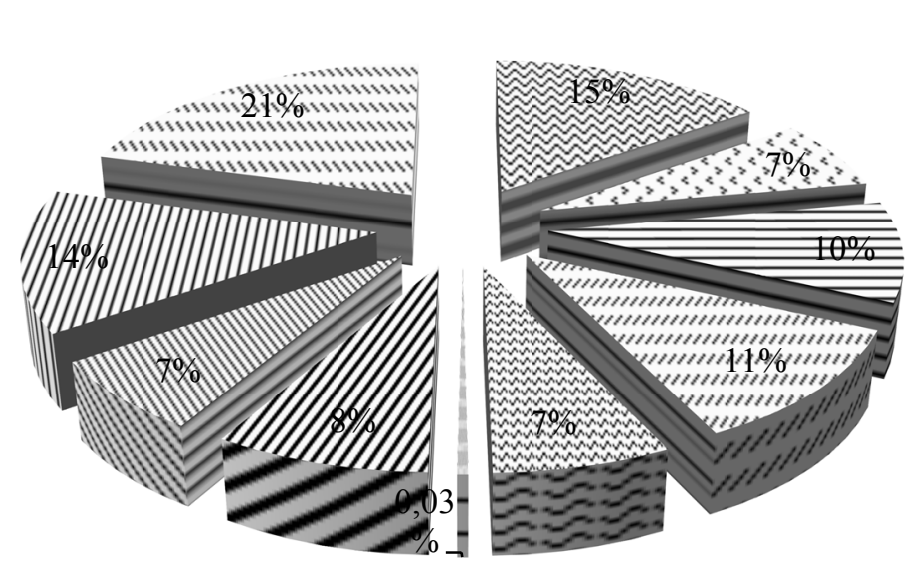

\author{
$\varpi$ Austria \\ $\because$ United Kingdom \\ = Denmark \\ "Italy \\ × Poland \\ $<$ Russia \\ C. Finland \\ « Czech Republic \\ I Switzerland \\ "Sweden
}

Figure 6. Share of organic farming of foreign countries

Most often, the French buy organic fruits and vegetables (73\%), eggs (61\%) and dairy products (49\%). Followed by bakery products $(41 \%)$, poultry $(24 \%) .23 \%$ of consumers buy eco-friendly wine and drinks. Especially foreign "organic market" - his consistently high growth - 10-20\% per year, with rates of ecological food prices outperform conventional products by at least $10-30 \%$. Production of organic food becomes profitable, primarily because of its property to reduce economic risks and increase economic and financial sustainability of such production. The basis for this are:

- $\quad$ independence from the purchase of means of production (fertilizers, plant protection products);

- the rejection of the use of genetically modified organisms (GMOs) at all stages of production;

- reducing production costs by reducing the cost (non-purchase of mineral fertilizers, synthetic plant protection products and animal feed; smaller (by 34-51\%) doses of applying soil nitrogen, phosphorus and other nutrients, the cost of local labor force);

- as a result of cost reduction actions and non-price factors demand organic products agribusiness become more competitive compared to similar products produced by traditional technology;

- uncivilized freedom from competition: high quality products contributes to the development of its own market environmentally friendly agricultural products;

- usually higher purchase price (Pollan, 2006).

\title{
4. Discussion
}

State environmental production in the Russian Federation, to some extent characterizes the current situation with the application of organic and mineral fertilizers in recent years, declining as a proportion of the area with fertilizers and the amount of fertilizers applied per unit area. For comparison: in 1990, mineral fertilizers were applied to $66 \%$ of acreage, organic fertilizers - by $7.4 \%$ in 2005 , respectively, only $32 \%$ and $3.4 \%$. One of the main reasons for this situation - the lack of enterprise funds not only to engage in ecological agriculture, but also in conventional production using chemical fertilizers.

Today there is the widespread public perception that environmentally friendly products enough "just to make the usual way". Under the "usual way of production" means the production of agricultural products in the shortage of funds, ie without application of mineral fertilizers, pesticides and other remedies.

Meanwhile, the production of environmentally friendly products involves the use of more complex and therefore more expensive technologies, even in comparison with intensive technologies. In addition to the use of organic fertilizers, you need to use natural plant protection products, as well as to maintain the required level of soil fertility.

Foreign requirements for organic certification require control over the production of products at all stages of production and include certification of the soil, seed and planting material, the final product of the enterprise.

In the European Union before the introduction of technologies for the production of environmentally friendly products, agriculture or farm must undergo a full inspection of the. Based on its results compiled a detailed description of the economy, including all rooms, storage and field system of proceedings and the date of last use 
of products not covered by organic technology. Only then begins to introduce a new system that does not allow the use of chemicals and protective measures that are not included in a special supplement. The entire production process chain is under constant supervision of the inspecting organization, which assigns each specific code of bio-products. Compulsory national or proprietary organic logos are also introduced.

To inform consumers need to specify the location where the organic food, including imported products bearing the logo of the European Union. Organic logo may be used only under the condition that $95 \%$ of the ingredients are organic food. Inorganic products may contain an indication of the organic origin of the individual components only in their list. In the production of organic products is strictly prohibited the use of genetically mo-the modified organisms (GMOs).

Development of the production of environmentally friendly products abroad is not only on farms with organic techniques. Agricultural scientists take active part of this, economists, environmentalists, who spend extensive scientific studies on specific aspects of organic agriculture. Methodology of Foreign Studies is built mainly on a comparison of the performance of farms with environmental and intensive technologies (Popkova et al., 2013).

Environmental specialists believe that further intensification of agricultural production is not possible, as will bring irreparable damage to the environment. The report, prepared by the UK consultants PG Economics, noted that with the reduction of pesticide use negative impact on the environment in the cultivation of biological cultures was $14 \%$ lower than for growing crops on conventional technologies. According to the report, the cultivation of biological plants and significantly reduced greenhouse gas emissions on the planet.

But organic farming reduces the productivity of rural producers, productivity and efficiency. The extent of biological agriculture depends on the state policy in this area, in particular, on the manner and extent of state support (Rashidi \& Keshavarzpour, 2011).

In the United States, due to changes in tax laws, rapidly growing production of ecologically pure milk American farmers become profitable to produce this labor-intensive product. Since June 2007, according to the "Amendment Harvey" cows from which use organic milk, should receive 100\% environmentally friendly food (previously permitted in feeding animals to use $20 \%$ of the forage crops grown in the traditional way). However, rising prices for bio-milk in this regard is not expected: the transition to entirely organic food from farmers requires additional costs that will be covered by the amounts released as a result of tax cuts (Greene \& Dmitri, 2003).

Experts predict that over the next few years, the annual increase in demand for eko-milky products will remain at 25\%. Major American manufacturers and wholesalers of dairy products - Dean Foods, Stonyfield Farm and Organic Valley - announced the production of new types of organic dairy products: milk powder, yogurt, ice cream and cheeses (Ottman, 1995).

In the UK, for example, payments to farmers engaged in organic farming, increased 2-fold, and in some countries is proposed to introduce a special tax on farmers using high doses of fertilizers and herbicides. The system of state support of agricultural enterprises in the European Union are the dominant elements of the grants based on the area of farmland and agricultural animal population, investment, social and other programs. Forms of state support of organic farming countries of Western Europe are presented in Table 1.

Table 1. State support for organic agriculture in Western Europe

\begin{tabular}{|c|c|c|c|}
\hline Countries & Period & Which contributed & Recipients of donations \\
\hline Germany & 1993 г. & EU-VO 2078/92 & Rebuild and reconstruct the economy \\
\hline Italy & $\begin{array}{l}1993-- \\
1996\end{array}$ & $\begin{array}{l}\text { The ability to export, domestic market } \\
\text { development, EC } 2078 / 92\end{array}$ & Rebuild the economy \\
\hline Denmark & 1994 & $\begin{array}{l}\text { Supermarket chain, unions Downstream of } \\
\text { dairy products }\end{array}$ & $\begin{array}{l}\text { Tunable economy, research, consulting, } \\
\text { monitoring, community service, sales }\end{array}$ \\
\hline Finland & 1995 & Accession to the EU & Rebuild the economy \\
\hline France & 1996 & Accession to the EU & Rebuild the economy \\
\hline Austria & $\begin{array}{l}1991 \text { г.; } \\
1994-- \\
1995\end{array}$ & $\begin{array}{l}\text { Soil and climatic conditions of grassland } \\
\text { farms, promotion on the federal level; }\end{array}$ & $\begin{array}{l}\text { Tunable economy, certification, } \\
\text { marketing; Rebuild the economy }\end{array}$ \\
\hline Sweden & $\begin{array}{l}1996-- \\
1998\end{array}$ & $\begin{array}{l}\text { Accession to the EU, a supermarket chain } \\
\text { in the domestic market }\end{array}$ & $\begin{array}{l}\text { Tunable economy, research, consulting, } \\
\text { marketing, control }\end{array}$ \\
\hline
\end{tabular}


For environmentally oriented enterprises are additional measures of state support at different levels - European, national (domestic) and municipal. Thus, the state can support environmental inspection, service of eko-consulting, sales and supply organizations, environmental and seed breeding farms, research institutions, associations, partnerships and special programs of ecological agriculture.

In the world operates a number of organizations that are involved in development and management of agro-ecological. In the first place, it is IFOAM (International Federation of Organic Agriculture Movements) The International Federation of Organic Agriculture Movements, which unites more than 100 countries. The participants in this organization includes Russia.

One of the main ways to support organic farming is the establishment and improvement of eco-standards. However, today in the world there are no common standards in the field of organic farming (Kama, 2003).

The main types of environmental standards can be classified into three groups:

a) international (intergovernmental framework) Standards:

- International basic standards IFOAM;

- Code of foods (Codex Alimentarius);

b) regional operating standards (directives), the national standards:

- EC Directive № 2092/91 “On environmental and agro-appropriate labeling of agricultural products and foodstuffs";

- American National Organic Program "NOC" USDA;

- Ecological farming program planning in Canada (EFP);

- Program of Canada's food safety and quality (CFCQP);

- Organic Program Australia;

- Japanese Agricultural Standard for organic products (Standard JAS);

- Standards of Switzerland;

- Standards of the Czech Republic ("Guidelines for organic farming" of the Ministry of Agriculture of the Czech Republic), and others. Countries;

c) private standards of ecological production, they are more than 260 .

The purpose of the international standards group " $\mathrm{A}$ " is to harmonize the various certification programs to create a universal framework for environmental standards worldwide. Basic operating standards group "B" establish the basic environmental requirements that must be met in relation to product and process of production of the labeled and relevant market, ie regu-liruyut certain environmental markets (Ottman, 1998).

According to the environmental standards of the private group "C", a business entity can be carried out in two different ways. This means that some of the fields may be processed by the rules of organic production, and another - by conventional methods, i.e. with the use of mineral fertilizers and pesticides. However, with few exceptions, the same culture cannot be grown ecological and conventional ways. Moreover, in this case, the production itself as well as certification of output power is complicated because of the many additional requirements of a clear division of production of conventional and organic food (Volosatova, 2006).

\section{Conclusion}

State support for producers of organic foods should be aimed not only at creating conditions for their production, but also the emergence of market structures that facilitate the implementation of environmentally friendly products. There is need for financial support to farmers producing organically grown foods, due to the appearance of additional costs during the transition period. In addition changes in technology crop in the early stages do not provide maintaining the same level of production and to some extent reduces the income. But the loss can be compensated for a higher price for its products.

Stimulating the production of organic foods is important not only in terms of saturation of the food market food products having certain characteristics, but also in terms of the orientation of agricultural production on the use of environment-friendly technologies for growing crops. Such techniques are widely used overseas. In Russia, a long time production of organic foods and appropriate technologies attention has not been given. Currently our country attempts to put into production of environmentally safe methods and techniques of growing crops. 
All they purport to exclude or minimize the use of chemicals. Stimulating the production of organic foods is important not only in terms of saturation of the food market food products having certain characteristics, but also in terms of the orientation of agricultural production on the use of environment-friendly technologies for growing crops. Such technologies are widely used overseas.

\section{References}

Cheng, S. (2006). Organic Diets Significantly Lower Children's Dietary Exposure to Organophisphorus Pesticides, 12(1), 16-18.

Danciu, V. (2005). Strategii de marketing. Editura Independenta Economica, Pitesti, 9(1), 17-21.

Danciu, V. (2006). Marketing ecologic. Etica verde aproductiei si consumului, Editura Economica, Bucuresti, $8(2), 4-6$.

Faix, W. G., Kurz, R., \& Wichert, F. (Hrgs). (1995). Inovation zwischen Okonomie und Okologie, Moderne Industrie Veltag, Landsberg. Lech, 2(1), 22-25.

Greene, C., \& Dmitri, C. (2003). Organic Agriculture: Gaining Ground, USDA. Economic Service, 6(1), 20-24.

Hopfenbeck, W., (1994). Umweltorientiertes Management und Marketing. Konzepte, Instrumente, Praxisspiele, 3. Auflage, Moderne Industrie Verlag, Landsberg. Lech, 9(1), 28-30.

Kama, J. (2003). Environmental Marketing: Strategy and its Implementation in First Industries. University of Helsinki Lu, 14(1), 55-59.

Ottman, J. (1995). Green Marketing. La sfida ambientale come opportunitaper il succeso dell` impressa, Il Sole 24 Ore. Libri Pirola S.P.A., 16(1), 34-35.

Ottman, J. (1998). Green Marketing: Opportunity for Innovation. Mc Graw Hill, 4(1), 15-19.

Pollan, M. (2006). Mass Natural: With WalMart, going organic, where will organic go?" New York Time Magazine, 3(1), 12-15.

Popkova, E. G., \& Tinyakova, V. I. (2013a). Dialectical Methodology of Analysis of Economic Growth. World Applied Sciences Journal, 24(4), 467-475.

Popkova, E. G., \& Tinyakova, V. I. (2013b). Drivers and Contradictions of Formation of New Quality of Economic Growth. Middle-East Journal of Scientific Research, 15(11), 1635-1640.

Popkova, E. G., Dubova Y. I., \& Romanova, M. K. (2013). Designing the Territorial Marketing Strategy on the Principles of Cluster Policies. World Applied Sciences Journal, 22(4), 571-576.

Popkova, E. G., Shachovskaya, L. S., \& Romanova, M. K. (2013). Bases of Transition of the Territory to Sustainable Development: Modern City. World Applied Sciences Journal, 23(11), 1499-1507.

Rashidi, M., \& Keshavarzpour, F. (2011). Classification of Tangerine Size and Shape Based on Mass and Outer Dimensions. Agricultural Engineering Research Journal, 1(3), 51-54.

Volosatova, U. A. (2006). Eco-branding as an instrument of environmental marketing. Reseedings of the Volgograd state technical university. Series "Actual problems of reforming the Russian economy (theory, practice, perspective)", 6, 205-208.

Volosatova, U. A. (2011). Economic content and nature as an integrated tool eko-marketing management decision-making process of buying. FES: Finance. Economy. Strategy. Series "Innovation Economy: the human dimension", 2, 16-20.

\section{Copyrights}

Copyright for this article is retained by the author(s), with first publication rights granted to the journal.

This is an open-access article distributed under the terms and conditions of the Creative Commons Attribution license (http://creativecommons.org/licenses/by/3.0/). 